\title{
Contribution of Environment in the Riverbanks and Peer Group to Drug Abuse
}

\author{
Dita Widiawati*, Nina Permata Sari, Eklys Cheseda Makaria \\ Program Study of Guidance and Counselling, Faculty of Teacher Training and Education \\ Lambung Mangkurat University \\ Banjarmasin, Indonesia \\ *ditaawidiawati1717@gmail.com,nina.bk@ulm.ac.id, eklys.makaria@ulm.ac.id
}

\begin{abstract}
Drug abuse is the use of narcotics, psychotropic substances and other addictive substances with the aim of having fun and without a doctor's recommendation. One of the things that influence drug use is peer groups. In addition, the social environment along the riverbanks which are residential areas can also influence drug use behavior. Therefore, this study aims to determine the contribution between the social environment in the riverbanks and peer groups to the drug abuse among adolescents in the sub-district of South Banjarmasin. This is quantitative study using the type of contribution research. The sample this study using purposive sampling technique, there were 301 people from 5 schools in South Banjarmasin sub-district. The result, model summary display $0.5 \%$ of the variation in drug use $(\mathrm{Y})$ can be explained by the variation of variables from the social environment along the river (X1) and peer groups (X2), while the rest $(\mathbf{9 9 . 5 \%})$ is explained by other reasons. The regression model for the social environment variable in the riverbank and peer groups is the level of significance, which is 0.544 , it can be concluded no contribution between the social environment in the riverbanks and peer groups with drug use among adolescents in South-Banjarmasin District.
\end{abstract}

Keywords—drug abuse, social environment at riverbanks, peer

\section{INTRODUCTION}

Students of 12-15 years old or who are in junior high school are early adolescents who experience physical and psychological development so that they can think critically and can make their choices according to their wishes. It means that early adolescents are no longer children in physical development or way of thinking or acting, but not mature adults [1]. It is common for the unstable students to be easily carried away by the condition of their environment, whether it is positive or negative behavior. Peer groups provide a place for adolescents to socialize in a group, where the prevailing values are based on their peers [2]

Drugs are narcotics, alcohol, psychotropic substances and addictive substances that are natural or synthetic, if misused cause changes in function and psychology, and addiction [3]. Basically, there are several types of drugs, but among the students they are often used by them are zenith, glue, inex, celedrile, amcodin, alcohol and oplosan. This type of drug is also relatively cheap and easy to get, so they are motivated to use it continuously. From the prevalence of drug use, the data obtained from the online news [4] states that based on data from the South Kalimantan National Narcotics Agency, drug use victims recorded around 60,000 people and $27 \%$ of them are the young generation. From the news circulating in 2019, Banjarmasin ranks 6 th out of 34 provinces as victims of drug use. From these data it can be said that drug use is already very developed in the younger generation. There are several factors that cause widespread drug use, one of it is due to the weak resistance of individuals to environmental influences such as association with smokers and drug addicts in neighbourhood [5]. It can be concluded that the influence of the social environment and social groups of students is very influential on behavior changes in these students.

Basically, nowadays students are easily influenced by the behavior of their association with social groups or peer groups. Nash et al [6] explained that a group is people who have certain norms and goals, who have an inner bond with one another. This means that a group is a group of people who gather because of the same goals and norms and between them have an inner bond with each other. Meanwhile, Rahmayanthi et al [7] explained that peers are children or adolescents with the same age or maturity level, having the same characteristics and culture. The environment greatly influences students in forming positive character development in themselves, someone will become an altruist because the environment provides real examples and directly seen by the individual [8]. If the peer group is positive, the actions they take are things that lead them to a positive direction, but on the other hand, if the peer group is negative, the actions they take will also lead them to a negative direction. In accordance with the competency standards for the independence of students and the development tasks of junior high school students regarding the maturity of relationships with peers where students will learn the norms of association with peers who have various backgrounds and must be aware of the diversity of peer backgrounds that underlie the association so that children can work well together and according to good norms [9]. The strong influence of peer groups on student behavior is corroborated by the results of research, showing that forms of 
deviant behavior by adolescents in the Alang river area of South Kalimantan, in the form of drunk, illegal racing, making noise at night [10]. From the strong influence of this peer group on students, it is very important for Guidance and Counselling teachers / counsellors to help guide and direct adolescents in social relationships, especially in peer group relationships, because if they are wrong in choosing peers, they are easily affected by behavior negatives such as drug use [11].

Leading to the environment in Banjarmasin which is known as the City of a Thousand Rivers because it has many rivers which are residential areas so that the majority of Banjarmasin residents are residents of the riverbanks. According to Law No.35 of 1991 [12] the riverbank is land on both sides along the riverbed from the edge to the inner embankment leg. From this definition it can be interpreted that the environment along the river means the community environment where their houses are located along the edge of the land on both sides of the riverbed. In line with the opinion of Kertodipoero [13] regarding rivers and human settlements in Kalimantan, the houses stand on poles, all facing the river, and each house has $\operatorname{logs}$ (footpath). He called the villages along the riverbanks a "station", which connected one village to another, and anyone who passed by could stop by. From the breadth of the riverbanks in Banjarmasin, researchers are also interested in focusing their research on the South Banjarmasin sub district where the area has 5 villages, namely West Kelayan I, West Kelayan II, East Kelayan, Pemurus, and Mantuil which are also included in the riverbank environment. From the results of observations, the results show that this area is classified as a slum area where the people there do not really care about the cleanliness of their home environment, such as dumping garbage in the river, carelessly and the arrangement of houses that are not neatly arranged. From the information obtained from one of the people who live there daily, it is said that many teenagers often gather or hang out together in the afternoon and even at night, it is common for them to be seen getting drunk and gluing. In addition to the results of observations made by researchers, researchers also found news [14] which states that the personnel of the Banjarmasin Police have arrested drug traffickers who are suspected of often selling to Ship Crew who docked in the waters of the Barito river, where the suspect lives in the Mantuil area which is also the South Banjarmasin District. As for the news from Banjarmasin tribunnews.com in December 2018, entitled "It's Fun to Glue Under the 27 Bridge, This Youth Group Doesn't Move when the Police Surround them" said that a group of teenagers used the under the bridge as a place to hang on. As was found at Jembatan 27, Jalan Mantuil, South Banjarmasin District, Banjarmasin City.

Along with the problem of drug use, this study wants to find out how the Figure of the social environment along the riverbanks against drug use and asks how the peer group describes the drug use by conducting research on the influence that occurs between the environment on the riverbank and peer groups on drug use entitled "Contribution between Social Environment on Riverbanks and Peer-Peer Groups Against Drug Abuse in Adolescent in South Banjarmasin District".

\section{METHODS}

This research uses quantitative research methods, this type of research contribution with the aim of research to find out whether there is a contribution between the social environment on the riverbank and peer groups on drug use in adolescents in South Banjarmasin District. The data collection technique was in the form of a questionnaire with a Likert scale. The research population is shown in Table 1.

TABLE I. RESEARCH POPULATION

\begin{tabular}{|l|l|l|l|}
\hline No & Sub-district & School & Population \\
\hline 1 & TanjungPagar & SMPN A & 360 \\
\hline 2 & Murung Raya & SMPN B & 662 \\
\hline 3 & Murung Raya & SMPN C & 177 \\
\hline 4 & Pemurus & SMPN D & 615 \\
\hline 5 & Basirih Selatan & SMPN E & 402 \\
\hline \multicolumn{2}{|l|}{ Total } & 5 & 2.216 \\
\hline
\end{tabular}

Table 1 shows the number of study populations, which are then sampled used purposive sampling, with the sampling criteria in this study were adolescents aged 12-15 years, attending school and residing in the South Banjarmasin District. The Likert scale of drug abuse, peer groups and the social environment on the riverbank is given to class VIII and class IX of 5 junior high schools in South Banjarmasin District, in total 301 people.

To determine the correlation simultaneously between two independent variables and the dependent variable in this study, this study was carried out by calculating multiple correlations with the formula. To find out the amount of correlation of the independent variables (X1 and X2) together on the dependent variable $(\mathrm{Y})$, the $\mathrm{F}$ test is used, with the formula: $\mathrm{F}=\mathrm{JKreg} /$ kJKres / (n-k-1). The F test is used to test the meaning of the relationship of all the independent variables $\mathrm{X} 1$ and $\mathrm{X} 2$ together (simultaneously) to the dependent variable Y [15].

\section{RESULTS}

Researchers conducted a number of tests as a requirement for data analysis in the form of normality tests, heteroscedasticity tests and multicollinearity tests. Table II and figure 1 show normality test results using KolmogorovSmirnov Test.

TABLE II. NORMALITY TEST

\begin{tabular}{|l|l|l|}
\hline \multicolumn{2}{|c|}{ One-Sample Kolmogorov-Smirnov Test } \\
\hline \multicolumn{2}{|c|}{} & \multicolumn{1}{|c|}{ Unstandardized Residual } \\
\hline \multirow{2}{*}{ Normal Parametersa,b } & Mean & 301 \\
\cline { 2 - 3 } & Std. Deviation & $0 \mathrm{E}-7$ \\
\hline \multirow{3}{*}{ Most Extreme Differences } & 7.19958194 \\
\cline { 2 - 3 } & Absolute & .066 \\
\cline { 2 - 3 } & Positive & .061 \\
\cline { 2 - 3 } & Negative & -.066 \\
\hline Kolmogorov-Smirnov Z & 1.150 \\
\hline Asymp. Sig. (2-tailed) & 142 \\
\hline
\end{tabular}

a. Test distribution is Normal b. Calculated from data 


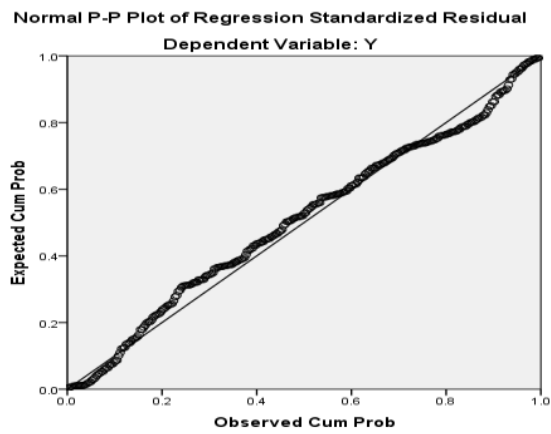

Fig. 1. Scatterplot normality test.

Based on the results of the normality test, it is known that the significant value is $0.142>0.05$, it can be concluded that the residual value is normally distributed. Table III and figure II shows the results of the multicolloremity test.

TABLE III. MULTICOLLINEARITY TEST

\begin{tabular}{|c|c|c|c|c|c|c|c|}
\hline \multicolumn{8}{|c|}{ Coefficients $^{\mathrm{a}}$} \\
\hline \multirow[t]{2}{*}{ Model } & \multicolumn{2}{|c|}{\begin{tabular}{|c} 
Unstandardized \\
Coefficients
\end{tabular}} & \multirow{2}{*}{\begin{tabular}{|c} 
Standardized \\
Coefficients
\end{tabular}} & \multirow[t]{2}{*}{$\mathbf{T}$} & \multirow[t]{2}{*}{ Sig. } & \multicolumn{2}{|c|}{$\begin{array}{c}\text { Collinearity } \\
\text { Statistics }\end{array}$} \\
\hline & B & \begin{tabular}{|c|} 
Std. \\
Error
\end{tabular} & & & & Tolerance & VIF \\
\hline (Constant) & 55.664 & 3.922 & & 14.194 & .000 & & \\
\hline $\begin{aligned} 1 & \begin{array}{l}\text { Social } \\
\text { environment } \\
\text { in riverbank }\end{array}\end{aligned}$ & -.035 & .035 & -.059 & -1.018 & .309 & .999 & 1.001 \\
\hline Peer group & -.015 & .025 & -.035 & -.608 & .544 & .999 & 1.001 \\
\hline
\end{tabular}

Based on the analysis of the results of tolerance is 0.999> 0.10 , it can be seen that there is no multicollinearity. Thus the results of the table analysis above the VIF are $1.001<10.00$, so that there is no multicollinearity.

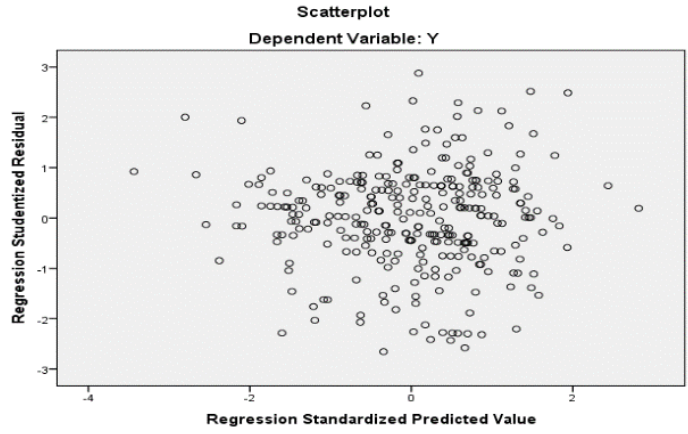

Fig. 2. Scatterplot of heteroscedasticity test.

From the scatterplot graph in figure 2, it can be seen that the dots are randomly distributed and well-spread. It can be concluded that there is no heteroscedasticity in the regression model, so the regression model is appropriate to be used to predict drug use based on the input of social environment variables on the riverbanks and peer groups.

\section{A. Hypothesis Test}

Hypothesis testing using summary model. Table IV showed the results of hypothetical testing calculations whether there is a contribution between the social environment on the riverbank and peer groups together against the abuse of drugs in adolescents in South Banjarmasin District.

TABLE IV. SOCIAL ENVIRONMENT CONTRIBUTION IN RIVERBANKS (X1) AND PEER GROUPS (X2) JOINTLY ON DRUG USE (Y).

\begin{tabular}{|l|l|l|l|l|}
\hline \multicolumn{4}{|c|}{ Model Summary } \\
\hline Model & R & R Square & Adjusted R Square & Std. Error of the Estimate \\
\hline 1 & $.070^{\mathrm{a}}$ & .005 & -.002 & 7.22370 \\
\hline
\end{tabular}

From the output model summary display of the SPSS computer program, the amount of adjusted R2 is 0.005 . This means that $0.5 \%$ of the variation in drug use (Y) can be explained by the variation of variables from the social environment along the river (X1) and drug use (X2). While the rest $(100 \%-0.5 \%=99.5 \%)$ is explained by reasons other than the model. Strengthening the calculation results of the model summary, the calculation is also carried out by using Test Statistic F. The calculation results are aimed at the table V.

TABle V. Calculations with the Simultaneous Significance TEST (TEST STATISTIC F)

\begin{tabular}{|c|c|c|c|c|c|}
\hline \multicolumn{6}{|c|}{ ANOVA $^{a}$} \\
\hline Model & Sum of Squares & Df & Mean Square & $\mathbf{F}$ & Sig. \\
\hline Regression & 75.620 & 2 & 37.810 & .725 & $.485^{\mathrm{b}}$ \\
\hline 1|Residual & 15550.194 & 298 & 52.182 & & \\
\hline Total & 15625.814 & 300 & & & \\
\hline
\end{tabular}

a. Dependent Variable: Y

b. Predictors: (Constant), X2, X1

From the ANOVA / F test, the calculated F value is 0.725 with a probability of 0.485 . Because the probability is much greater than 0.05 , the regression model can be used to predict drug use (Y) or it can be said that social environmental variables on riverbanks (X1) and peer groups (X2) do not contribute to drug use (Y).

Then the hypothetical analysis can also be done by using the T Test as follows in table VI:

TABLE VI. SIGNIFICANCE TEST OF INDIVIDUAL PARAMETERS (T STATISTICAL TEST)

\begin{tabular}{|c|c|c|c|c|c|}
\hline \multicolumn{6}{|c|}{ Coefficients $^{\mathrm{a}}$} \\
\hline \multirow[t]{2}{*}{ Model } & \multicolumn{2}{|c|}{$\begin{array}{l}\text { Unstandardized } \\
\text { Coefficients }\end{array}$} & \multirow{2}{*}{\begin{tabular}{|c|}
$\begin{array}{c}\text { Standardized } \\
\text { Coefficients }\end{array}$ \\
Beta \\
\end{tabular}} & \multirow[t]{2}{*}{$\mathbf{t}$} & \multirow[t]{2}{*}{ Sig. } \\
\hline & $B$ & Std. Error & & & \\
\hline (Constant) & 55.664 & 3.922 & & 14.194 & .000 \\
\hline $\mathrm{X} 1$ & -.035 & .035 & -.059 & -1.018 & .309 \\
\hline $\mathrm{x} 2$ & -.015 & .025 & -.035 & -.608 & .544 \\
\hline
\end{tabular}

a. Dependent Variable: Y 
From the data above, what is entered into the regression model for the social environment variable at the riverbank (X1) and peer groups (X2) is the level of significance. This can be seen from the significance probability for drug use (X2) which is 0.544 , which is greater than 0.05 . So it can be concluded that the null hypothesis ( $\mathrm{H} 0)$ is proven, that there is no contribution between the social environment on the riverbanks and peer groups with drug use among adolescents in South Banjarmasin District.

\section{DISCUSSIONS}

Based on the results of hypothesis testing using multiple analysis techniques that have been carried out in this study, it shows that the alternative hypothesis ( $\mathrm{Ha}$ ) is rejected and states that there is no significant contribution between the social environment along the river to drug use in adolescents in South Banjarmasin District. This is confirmed based on the known Figure that the social riverbanks in South Banjarmasin District which have strong social interaction and the description of adolescents in South Banjarmasin District who reject or disagree with drug use. So it can be concluded that the strong interaction in the riverbank social environment in South Banjarmasin District is possible to produce social control which can prevent social deviations such as drug use.

This result is in line with the research conducted $[13,16]$, saying that until now rivers still play an important role in the interaction between community members, where strong interaction between community members can result in social control. Social control is a business or a mechanism carried out by the community to prevent social deviations and direct people to behave according to prevailing norms and values [17].

In addition, based on the results of the hypothesis test conducted, it also concluded that the alternative hypothesis (Ha) was rejected, and stated that there was no significant contribution between peer groups and drug use in South Banjarmasin Sub-district. This is confirmed by the results of the description of peer groups among adolescents in South Banjarmasin District which provide a positive role, this is seen from the psychological / social support that exists in their peer group which is so strong, such as being appreciated when telling stories, providing mutual assistance, and mutual assistance. Strengthening when there are friends who have problems with psychological / social support, it is possible to increase adolescent self-confidence so that they are not easily affected by negative things, are able to deal with problems / prevent stress, and have an attitude of disapproval of drug use.

This is in accordance with the opinion of several research explaining that social support is attention, compassion, and empathy that can support individual self-confidence so that these individuals are not easily affected by the negativity of stressful conditions, can foster a sense that they are able to face various problems in life and with the higher self-confidence of adolescents, the higher the adolescent's disagreement with drug use [18-22]. As for Situmorang [23] in his research explained that based on the data analysis that had been carried out, peer groups in Batukarang Village played a positive role in their peer groups such as providing social, moral, and emotional support so that they could prevent drug abuse.

Based on the results of testing and discussion that have been described, it can be concluded that there is no significant contribution between the social environment on the riverbank and peer groups to drug use among adolescents in South Banjarmasin District, which means that the alternative hypothesis (Ha) is rejected. This conclusion is seen from the results of the coefficient of determination which shows an $\mathrm{R}$ square value of 0.05 , this indicates that the social environment on the riverbanks and peer groups to the drug use variable is $0.5 \%$, this shows a very small percentage of the contribution between the social environment. Along the river and peer groups against drug use in adolescents in South Banjarmasin District. The Effective Contribution (SE) of the social environment variables along the river to drug use was $0.4 \%$, while the Effective Contribution (SE) of the peer group variable on drug use was $0.1 \%$.

It is suspected that the cause of the absence of a contribution between the social environment on the riverbanks and peer groups to drug use is because the riverbank social environment in South Banjarmasin District has quite strong interactions such as night watch by RT / residents, as well as the association of women. Talking while carrying out their activities on the banks of the river, which in turn can control the conditions of the living environment and create care for one another. From these interactions, it can increase social control / social control in the surrounding community so that it can prevent deviant behavior such as drug use, coupled with the condition of peer groups that exist in adolescents in the South Banjarmasin sub-district giving a positive role.

This is supported by the opinion expressed by several research saying that with sufficiently strong interaction in society such as creating community organizations that focus on monitoring the environment in which they live (Ronda) so that it can lead to social control which aims to prevent violations and to restore / cure the violations that have occurred $[16,22,24]$. Interaction can also be in the form of psychological / social support received from the environment and peer groups so that it can provide a sense of comfort and high selfconfidence. The higher the self-confidence, the adolescents will have a disapproving attitude towards drug use.

In addition, in terms of education, the local government facilitates access for riverbank communities to get education, because there are already several schools that are located right on the riverbanks, especially in the Martapura river area itself. Like elementary and junior high schools and even high schools there are already standing close to the Martapura river. So that the people on the banks of the Martapura river, especially teenagers and children, already have sufficient knowledge and insight about the dangers of drugs [25]. Local governments have also begun to pay special attention to underdeveloped areas in southern Kalimantan to develop their natural and 
human resources so that the economic level of their people increases and has a positive impact on the environment [26].

The results of other research that can be compared with the results of this study are the results of research explaining that the causes of drug use are seen from personality factors, namely because the level of self-confidence is still very low, the ability of respondents to overcome personal problems faced is still very minimal and the wrong education about drugs [27]. As well as seen from the social / community conditions, drug use is caused by neighbours and people around the neighbourhood where the respondent lives do not care about each other. One of the respondents stated that drug use can be reduced through social control / social control in the community. This can be done through legislation (UU), drug education, and socializing with the surrounding social environment.

\section{CONCLUSION}

Based on the results of research conducted on the contribution between the social environment on the riverbank and peer groups against the abuse of drugs in adolescents in South Banjarmasin sub district, it can be concluded there is no contribution between the social environment on the riverbank and peer groups on drug use among adolescents in South Banjarmasin District.

\section{REFERENCES}

[1] R. Marliani, Psikologi Perkembangan. Bandung: Pustaka Setia, 2015

[2] A. Rachman and N.P. Sari, "Pengaruh Teman Sebaya Dan Kepercayaan Diri Terhadap Aktualisasi Diri Mahasiswa," Jurnal Psikologi Pendidikan dan Konseling: Jurnal Kajian Psikologi Pendidikan dan Bimbingan Konseling, vol.5, pp. 9-19, 2019.

[3] H.D. Saleh, D. Rokhmah and I. Nafikadini, "Fenomena Penyalahgunaan NAPZA Di Kalangan Remaja Ditinjau Dari Teori Interaksionisme Simbolik Di Kabupaten Jember (The Phenomenon of Substance Abuse among Adolescents Based on Symbolic Interactionism Theory in Jember Regency)," e-Journal Pustaka Kesehatan, vol. 2, no. 3, pp. 468-475, 2014

[4] Jejakrekam, Pengguna Narkoba di Kalsel Sudah Capai 60.000 Orang [Online]. Retrieved from: http://jejakrekam.com/2019/12/24/penggunanarkoba-di-kalsel/, 2019

[5] F. Schifano, S. Chiappini, J.M. Corkery and A. Guirguis, "An insight into Z-drug abuse and dependence: an examination of reports to the European medicines agency database of suspected adverse drug reactions," International Journal of Neuropsychopharmacology, vol. 22, no. 4, pp. 270-277, 2019.

[6] A.J. Nash, E.A. Hennessy and C. Collier, "Exploring recovery capital among adolescents in an alternative peer group," Drug and Alcohol Dependence, vol. 199, pp. 136-143, 2019.

[7] R. Rahmayanthi, I. Ilfiandra and S. Yusuf, "Profil Komformitas Teman Sebaya Berdasarkan Faktor Demografi," Indonesian Journal of Educational Counseling, vol. 4, pp. 65-74, 2020.

[8] N.P. Sari, M.A. Setiawan and R. Andriani, Bimbingan dan Konseling Perspektif Indigenous: Etnik Banjar. Jogjakarta: DeePublish, 2020.

[9] A. Susanto, Bimbingan dan Konseling di Sekolah: Konsep, Teori dan Aplikasinya. Jakarta: Prenamedia Group, 2018.
[10] M. Ihsan, "Perilaku Menyimpang Remaja Desa Sungai Alang Kecamatan Karang Intan Kabupaten Banjar Kalimantan Selatan,” Jurnal Pendidikan Kewarganegaraan, vol. 4, no. 8, 2014.

[11] L.C. Masland and A.M. Lease, "Effects of achievement motivation, social identity, and peer group norms on academic conformity," Social Psychology of Education, vol. 16, pp. 661-681, 2013.

[12] A. Maryono, Pengelolaan Kawasan Sempadan Sungai. Jogjakarta: UGM Press, 2020

[13] R. Rochgiyanti, "Fungsi Sungai Bagi Masyarakat di Tepian Sungai Kuin Kota Banjarmasim dalam Komunitas," International Journal of Indonesian Society and Culture, vol. 3, pp. 51-59, 2011.

[14] Radar Banjarmasin, Pengedar Narkoba Khusus Jalur Sungai di Ciduk Begini Modusnya [Online]. Retrieved from: http://m.kalsel.prokal.co/read/news/14907-pengedar-narkoba-khususjalur-sungai-diciduk-begini-modusnya.html, Accessed on: 28 April 2018

[15] S. Margono, Metodologi Penelitian Pendidikan. Jakarta: Rineka Cipta, 2014.

[16] A.R. Yohannis and H. Sastramihardja, Model Pengendalian Sosial Pada Komunitas Situs Jejaring Sosial, 2010.

[17] H.G. Pradana and M. Mustofa, Pengendalian Social Swadaya Sebaga Reaksi Dari Slank Dan Slankers Terhadap Kerusuhan Dalam Konser Slank [Online]. Retrieved from: http://eprints.ums.ac.id/48360/34/naskah\%20publikasi.pdf, Accessed on: 20 September 2019.

[18] N. Niven, Psikologi Kesehatan Pengantar Untuk Perawat Dan Profesional Kesehatan Lain. Alihbahasa Agung Waluyo Edisi 2. Jakarta: EGC, 2002.

[19] F. Fadhil, Pengaruh Dukungan Sosial Teman Sebaya Terhadap Resiliensi Remaja Di SMA Banda Aceh [Online]. Retrieved from: http://jurnal.unsyiah.ac.id/suloh/article/view/14151/10691, Accessed on: 2018 , Sept 20

[20] J. Jenaabad, "The Relationship Between Perceiveed Social Support And Blind And Low-Vision Students' Lif Satisfaction And Instructional Studies In The Word," vol.3, pp. 13-17, 2013.

[21] E.S. Tiwiyati, Hubungan Antara Dukungan Sosial Dengan Kepercayaan Diri Pada Siswa SMA Inklusi [Online]. Retrieved from: http://eprints.ums.ac.id/48360/34/naskah\%20publikasi.pdf, Accessed on 17 Oct 2016.

[22] M. Yunus, Faktor-Faktor Yang Mempengaruhi Remaja Putra Terhadap Penggunaan Narkoba Di Desa Meureubo Kecamatan Meureibo Kabupaten Aceh Barat (Doctoral dissertation, Universitas Teuku Umar Meulaboh), 2013

[23] D.N. Situmorang, Peranan Kelompok Teman Sebaya (Peer Group) dalam Pencegahan Penyalahgunaan Narkoba di Desa Batukarang Kecamatan Payung Kabupaten Karo, 2018

[24] M. Zainuddin and A. Agustang, "Kontrol Sosial Orangtua Terhadap Penggunaan Smartphone Pada Remaja (Studi Di Desa Giring-Giring Kecamatan Bontonmpo Kabupaten Gowa," Jurnal Sosialisasi: Jurnal Hasil Pemikiran, Penelitian dan Pengembangan Keilmuan Sosiologi Pendidikan, pp. 68-73, 2019.

[25] M.A. Setiawan and N.P. Sari, Kumpulan Esai Anak-anak Sungai: Sketsa Masyarakat Bantaran Sungai dalam Perspektif Bimbingan dan Konseling. Yogyakarta: Deepublish, 2019

[26] M. Mutiani, J.A. Lestari, J. Jumriani, N.P. Sari, S. Syaharuddin and E.W. Abbas, "Study on Economic Values Throught The Activities of The Manager in Kampung Purun Palam Village-Banjarbaru," International Journal of Psychosocial Rehabilitation, vol. 24, pp. 10-21, 2020

[27] P. Anggoro, "Faktor Penyebab Penyalahgunaan Napza di Kalangan Remaja Instalasi Rehabilitasi Wisma Sirih," Jurnal Pendidikan dan Pembelajaran Khatulistiwa, vol. 6, no. 6 